Vesna Paraušić ${ }^{1 *}$, Ivana Simeunović ${ }^{2}$, Darko B. Vuković ${ }^{3}$

${ }^{1}$ Institute of Agricultural Economics, Belgrade

* Corresponding author, e-mail: vesna_pa@iep.bg.ac.rs

2 Belgrade Banking Academy, Belgrade

${ }^{3}$ Geographical Institute Jovan Cvijic of Serbian Academy of Sciences and Arts

\title{
SERBIAN AGRICULTURAL COMPETITIVENESS
}

ABSTRACT. Agricultural sector in Serbia is characterized by low competitiveness, as well as by domination of small agricultural husbandries of low productivity and production intensity. The authors of the paper, based on secondary sources, i.e. the analysis of numerous domestic and foreign documents in the field of agriculture, economic and rural development, provide state analysis of agricultural sector in Serbia, as well as a proposal of measures for improvement of this production and development of competitive and attractive rural regions.

KEY WORDS: agricultural sector, rural regions, competitiveness.

\section{INTRODUCTION}

The current extent and structure of agricultural production in Serbia, its high extensiveness, oscillatory, low productivity (resulted from multi-decade disinvestment), along with inefficient organization of production - circulations, represent basic factors which limit the competitiveness of domestic producers and exporters on the international market of agro-food products. Besides, numerous institutionalinfrastructural obstructions and macroeconomic instability (high macroeconomic and total risk of the government, inefficient legislature and judiciary, under developed financial markets, under developed physical infrastructure, weak institutions), have a direct reflection to this economy field, too.

Development of rural areas substantially depends on agriculture development and greater investments in this production. Simultaneously, the greater investments in agricultural sector are caused by lower price of capital, i.e. by favourable macro-economic and business environment of the country, as well as a low non-commercial risk of the country. In that way, all assumptions of the competitiveness growth of domestic agriculture and rural areas remain dominantly on the macro-economic level.

In the paper, the authors will research the level of agricultural production competitiveness in Serbia and point out to further development directions of this production, of which will depend, to a large degree, upturn and development of rural areas and balanced regional development of the country.

\section{ROLE OF AGRICULTURAL PRODUCTION IN THE NATIONAL ECONOMY OF THE REPUBLIC OF SERBIA}

The sector of agriculture and rural development comprises agricultural production, forestry, fishery, food safety, animal welfare and rural development. This sector represents an important factor of the total national economy, from the aspect of share in gross value added, employment, and current account of the balance of payments. This situation is a product of two basic factors [National priorities for the international assistance for the period 20142017, with projections up to 2020, p. 222]:

a) Slow rate of restructuring in other sectors, which lead to weak investment activities 
and consequentially poor opportunities for employment in the sectors beyond agriculture,

b) Availability of rich natural resources for agricultural production in the Republic of Serbia.

The following data lead to significance of agricultural and rural sector for the national economy.

I. The share of activity "Agriculture, forestry and fishery", in gross added value of the Republic of Serbia in 2011 was amounted 10.5\%, and, together with production of food products, beverages and tobacco, the agro-food sector makes $16.0 \%$ of gross added value of all activities in the Republic of Serbia [Statistical Yearbook of the Republic of Serbia, 2013, pp. 130, 132]. According to data of the World Bank, the agriculture in Serbia participates with 9\% in gross domestic product (2011), which is significantly higher than in regard to developed European countries (Table 1).

II. According to data of the World Bank (Table 1), Serbia has been characterized by high employment in the activity sector "Agriculture, forestry and fishery", especially in regard to high-developed European countries (Table 1). According to data of the Labour Survey of the Statistical Office of the Republic of Serbia [Bulletin 578, 2014, p. 56] in 2013, in employees structure in the Republic of Serbia, in the activity sector "Agriculture, forestry and fishery" was employed $21.3 \%$ employees, and in rural areas even 43.9\%. Informal employment in the Republic of Serbia in the year 2013 was amounted 19.3\% (in rural areas 34.5\%), and in the activity sector "Agriculture, forestry and fishery" in rural areas, the informal employment was achieved up to $64.4 \%$ [the Labour Survey, 2013, Bulletin 578, pp. 59-60].

III. Serbia has been realizing a positive trend in foreign trade exchange of agro-food products with the world. The export of agrofood products (group "Food and live animals") was increased from 924 million USD in 2005
Table 1. Share of agriculture in gross domestic product (GDP) and employment in agriculture in selected European countries

\begin{tabular}{|c|c|c|}
\hline Countries & $\begin{array}{c}\text { Agriculture/ } \\
\text { value added, } \\
\% \text { of GDP, } \\
2011^{1}\end{array}$ & $\begin{array}{c}\text { Employment } \\
\text { in agriculture, } \\
\% \text { of the total } \\
\text { employment, } \\
2012^{2}\end{array}$ \\
\hline \multicolumn{3}{|c|}{ High-developed economies } \\
\hline Austria & 1.5 & 4.9 \\
\hline Belgium & 0.7 & 1.2 \\
\hline Czech Republic & 2.3 & 3.1 \\
\hline Denmark & 1.2 & 2.6 \\
\hline France & 1.8 & 2.9 \\
\hline Germany & 0.9 & 1.5 \\
\hline Italy & 1.9 & 3.7 \\
\hline The Netherlands & 2.0 & 2.5 \\
\hline Norway & 1.6 & 2.2 \\
\hline Portugal & 2.4 & 10.5 \\
\hline Slovakia & 3.9 & 3.2 \\
\hline Slovenia & 2.5 & 8.3 \\
\hline Spain & 2.7 & 4.4 \\
\hline Sweden & 1.8 & 2.0 \\
\hline Great Britain & 0.7 & 1.2 \\
\hline \multicolumn{3}{|c|}{ Central and East Europe countries } \\
\hline Albania & 18.6 & 42.0 \\
\hline Bosnia \& Herzegovina & 8.7 & 20.5 \\
\hline Bulgaria & 5.6 & 6.4 \\
\hline Croatia & 5.1 & 13.7 \\
\hline Hungary & 3.5 & 5.2 \\
\hline Poland & 3.5 & 12.6 \\
\hline Romania & 7.4 & 29.0 \\
\hline Serbia & 9.0 & 21.0 \\
\hline \multicolumn{3}{|c|}{ Ex-USSR countries } \\
\hline Armenia & 20.7 & 38.9 \\
\hline Azerbaijan & 5.8 & 37.7 \\
\hline Byelorussia & 9.9 & - \\
\hline Georgia & 9.3 & - \\
\hline Russian Federation & 4.3 & - \\
\hline Ukraine & 9.6 & 17.2 \\
\hline
\end{tabular}

Source: The World Bank, http://data.worldbank.org/ indicator/NV.AGR.TOTL.ZS,

http://data.worldbank.org/indicator/SL.AGR.EMPL.ZS/ countries?display=default, access date $3^{\text {rd }}$ May 2014.

1 Agriculture encircles crop and livestock production, forestry, hunting and fishery. For high-developed countries, Poland and Hungary the data refer to the year 2010, and for France the data is for the year 2009.

2 Data for employment: Albania (2010), Armenia (2011), the Netherlands (2011). 


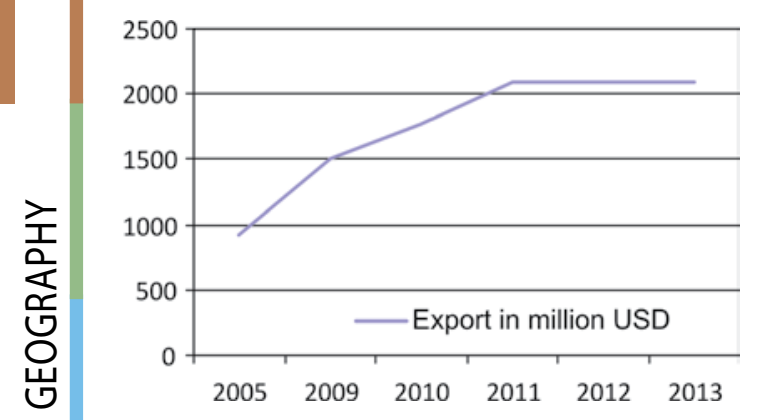

Fig. 1. Export of "Food and live animals" from Serbia in the period 2005-2013.

Source: Calculation of the authors according to data of the SORS for the corresponding years.

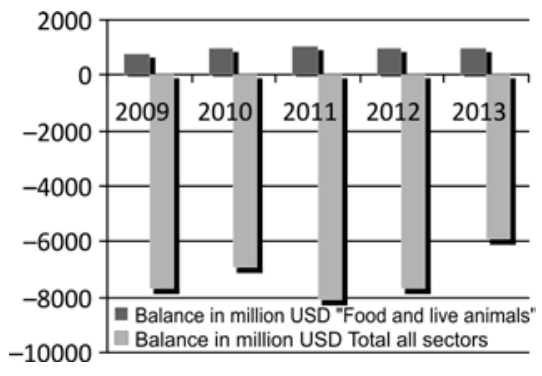

Fig. 2. Balance of foreign trade exchange in export of "Food and live animals" and all sectors, in the period 2009-2013.

Source: Calculation of the authors according to the SORS data.

to 2.1 milliards USD in 2013, i.e. for 127\% (Fig. 1). Besides, Serbia provides market surpluses of many agricultural products which are export-oriented (fruits, cereals, sugar), and agro-food sector of Serbia has been, in years, the only sector in the national economy with surplus in foreign trade exchange (Fig. 2). The surplus in foreign trade exchange of agrofood products, in the period 2005-2013, had ranged from 150 million USD (2005) to 949 million USD (2013).

IV. Rural areas of Serbia occupy $85 \%$ of Serbian territory, $55 \%$ of population live in them and they form $41 \%$ of the country's GDP [Bogdanov, 2007, p. 31]. Although in agriculture of Serbia dominate, so called, small and medium agricultural husbandries (according to data of the Agricultural Census in 2012, even $77.4 \%$ of the total number of agricultural husbandries in Serbia, with utilised agricultural area, have property to
5 hectares), these husbandries have great significance on the local commodity market from food production point of view (selfsufficiency rate and food safety), as well as from the resources preservation and rural environment point of view [see Draft Strategy of Agriculture and Rural Development of Serbia in the period 2014-2024, p. 55].

V. The Republic of Serbia has favourable factorial conditions (good geographic location of the country, high diversity of rural areas, high-quality and unpolluted agricultural land, water resources) for development of intensive agriculture, as well as liberalized agricultural products trade with many countries: surrounding countries (CEFTA Agreement), possibility of preferential export for strategic products in the EU, USA, Russian Federation etc. More on the trade agreement and foreign trade agreements can be seen at the internet SIEPA presentation [http://siepa.gov.rs/sr/index/sporazumi, date of access $5^{\text {th }}$ April 2014].

\section{EVALUATION OF AGRICULTURAL COMPETITIVENESS IN THE REPUBLIC OF SERBIA}

Besides all mentioned in the previous item, the competitiveness of agricultural sector on domestic and international market has been extremely high [see Paraušić et al., 2013, pp. 158-171; Paraušić, Cvijanović, 2014]. In accordance to research of the group of authors, the only competitive advantage of rural areas in the countries of West Balkan, to which belongs also the Republic of Serbia, are [Stantič, 2011, p. 2]: (1) low labour price and (2) high quality natural resources.

The most important indicators of Serbian agricultural sector non-competitiveness are given below.

I. Low export value of agricultural products per a hectare of utilised agricultural area in regard to the EU countries (Table 2, Fig. 3).

Low export results are the result of unfavourable export structure, low export 
Table 2. Export of agricultural products from Serbia and selected EU countries, 2012.

\begin{tabular}{|c|c|c|c|c|}
\hline & UAA $^{1}, 2010$ & $\begin{array}{c}\text { Export of agro } \\
\text { products in the } \\
\text { total export } \\
\text { of commodities, \% }\end{array}$ & $\begin{array}{c}\text { Export } \\
\text { of agricultural } \\
\text { products } \\
\text { in } 000 \text { US\$ }\end{array}$ & $\begin{array}{c}\text { Export } \\
\text { of agricultural } \\
\text { products per ha } \\
\text { of UAA in } 000 \text { US\$ }\end{array}$ \\
\hline The Netherlands & $1,872.350$ & 15.7 & $102,944.900$ & 54,982 \\
\hline Austria & $2,878.170$ & 9.5 & $15,811.705$ & 5,494 \\
\hline Italy & $12,856.050$ & 8.5 & $42,561.115$ & 3,311 \\
\hline France & $27,837.290$ & 13.8 & $78,510.960$ & 2,820 \\
\hline Spain & $23,752.690$ & 16.8 & $49,381.752$ & 2,079 \\
\hline Greece & $3,477.900$ & 19.4 & $6,882.926$ & 1,979 \\
\hline Serbia & $3,437.423$ & 25.0 & $2,838.250$ & 826 \\
\hline
\end{tabular}

1 UAA - The utilised agricultural area (UAA) describes the area used for farming. It includes the land categories: arable land; permanent grassland; permanent crops, and other agricultural land such as kitchen gardens (even if they only represent small share of the total UAA). The term does not include unused agricultural land, woodland and land occupied by buildings, farmyards, tracks, ponds, and so on. For Serbia data for 2012. In Greece common land is excluded.

Source: For UAA data of the Eurostat, http://epp.eurostat.ec.europa.eu, access date $10^{\text {th }}$ May 2014. For agricultural products data of the WTO statistics database for 2012, http://stat.wto.org/Home/WSDBHome.aspx?Language=, access date $10^{\text {th }}$ March 2014.

unit value, impossibility of realizing price competitiveness on the foreign market, impossibility of providing sufficient amounts of commodity for export, as well as providing continuity in supply of the international market with products of homogenous quality. Especially, a great problem is unfavourable export structure of agrofood products. Serbia has a small number of products in the sector "Food and Live Animals" in which exchange it makes a high surplus. Those are, primarily, stock market products: cereals (especially maize), berries (dominantly frozen raspberry and sour cherry), refined sugar, and the prices of those

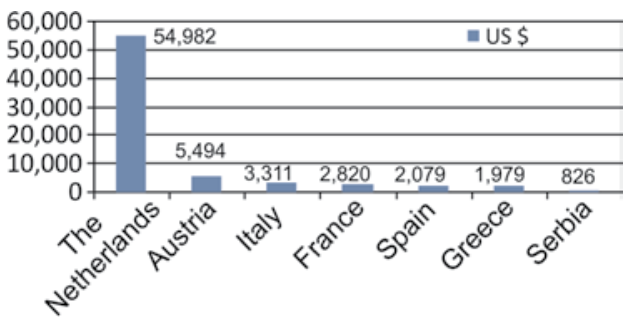

Fig. 3. Export of agricultural products per ha of UAA, in 2012, in selected European countries and Serbia.

Source: Calculation of the authors according to the data in Table 2. products are determined by the world food market, where the price is the only basis for applying. The unfavourable export structure (domination of primary products, small share of manufacturing articles, especially those based on meat and milk), causes a low unit and total value of food export. The presented data (Table 2, Fig. 3) point out to the fact that deficiency or inappropriate quality of agricultural area is not a limiting factor for high competitiveness in the agricultural sector (the example of the Netherlands), and vice versa, that the favourable factorial conditions in the field of agriculture must not "lead" to high export results and high competitiveness of agriculture (the example of Serbia).

II. Extensiveness (low productivity) of agriculture is a result of low support from the agrarian budget and under developed and unfavourable financial market for higher investments in modernization and consolidation of agricultural. The agricultural investments are of the essential significance for promoting the agricultural growth, poverty reduction and preservation of the environment [The State of food and agriculture, 2012], and their deficiency 
leads to an extensive agriculture, highly dependable of climatic factors. In accordance to data on productivity in agriculture for the selected countries, which are presented through indicators "Agriculture, added value per an employee" (Table 3), can be seen that productivity in the Republic of Serbia, in the field of agriculture, is far lower in regard to high-developed European countries, as well as that lower productivity than Serbia, in agriculture, have the following countries: Albania, Azerbaijan and Georgia.

For data on livestock breeding share in the total agricultural production value: FAO Statistics, http://faostat.fao.org, access date $15^{\text {th }}$ May 2014.

\section{Low share of livestock production in value} of the total agricultural production. The livestock breeding has great significance and multiple roles in valorisation of working and production potentials in agriculture of every country. The share of livestock breeding in value of the total agricultural production in the Republic of Serbia amounts 34.2\% for the year 2011 (FAO data, Table 3) and this is significantly lower share in regard to the selected high-developed countries. The livestock production of Serbia is characterized by numerous financial, organizational-market problems, as well as deficiency of set and efficient market connections between the primary agricultural producers, forestallers, exporters and meat processors, owing to which this production records a permanent decline [see more Paraušić et al., 2010].

\section{CONSEQUENCES OF AGRICULTURAL NON-COMPETITIVENESS OF THE REPUBLIC OF SERBIA}

Deficiency of Serbian agricultural competitiveness has a series of negative implications on economic and regional development of the Republic of Serbia, and the most important are as follows:

I. Lack of long-term and stable growth of agricultural production. According to the SORS data [Statistical Yearbook, 2011, 2013] in 2008,
Table 3. Productivity in agriculture and share of livestock breeding in value of the total agricultural production

\begin{tabular}{|c|c|c|}
\hline & $\begin{array}{c}\text { Agricul- } \\
\text { ture, value } \\
\text { added per } \\
\text { employee, } \\
\text { permanent } \\
\text { prices } 2005 \\
\text { US\$, } 2012^{1}\end{array}$ & $\begin{array}{c}\text { Share } \\
\text { of livestock } \\
\text { breeding in } \\
\text { value of the } \\
\text { total agricultural } \\
\text { production } \\
\text { in } \%, 2011^{2}\end{array}$ \\
\hline \multicolumn{3}{|c|}{ High-developed economies } \\
\hline Austria & 33,213 & 58.4 \\
\hline Belgium & 56,515 & 55.8 \\
\hline Czech Republic & 6,680 & 53.4 \\
\hline Denmark & 31,885 & 71.8 \\
\hline France & 75,178 & 44.9 \\
\hline Germany & 31,641 & 62.6 \\
\hline Italy & 43,151 & 35.2 \\
\hline The Netherlands & 60,398 & 66.6 \\
\hline Norway & 65,249 & 76.5 \\
\hline Portugal & 8,906 & 43.9 \\
\hline Slovakia & 12,735 & 45.2 \\
\hline Slovenia & 112,484 & 62.2 \\
\hline Spain & 33,681 & 35.6 \\
\hline Sweden & 38,006 & 67.4 \\
\hline Great Britain & 28,466 & 59.8 \\
\hline \multicolumn{3}{|c|}{ Central and East Europe countries } \\
\hline Albania & 3,630 & 51.7 \\
\hline $\begin{array}{l}\text { Bosnia \& Herze- } \\
\text { govina }\end{array}$ & 28,183 & 38.1 \\
\hline Bulgaria & 16,101 & 36.2 \\
\hline Croatia & 23,521 & 37.5 \\
\hline Hungary & 9,964 & 43.1 \\
\hline Poland & 4,111 & 57.2 \\
\hline Romania & 9,117 & 33.9 \\
\hline Serbia & 3,904 & 34.2 \\
\hline \multicolumn{3}{|c|}{ Ex-USSR countries } \\
\hline Armenia & 8,389 & 41.5 \\
\hline Azerbaijan & 1,085 & 42.7 \\
\hline Byelorussia & 7,845 & 49.8 \\
\hline Georgia & 2,512 & 45.4 \\
\hline Russian Federation & 5,969 & 50.0 \\
\hline Ukraine & 4,375 & 31.4 \\
\hline
\end{tabular}

1 Agriculture includes value added of forestry, hunting, fishery, as well as of crop and livestock production. For the Slovakian Republic (2010); Slovenia (2010); Hungary (2010); Poland (2010); Serbia (2009).

2 Gross production value, permanent prices 2004-2006 in million USD.

Source: For data on productivity (Agriculture, value added per an employee): The World Bank, http:// data.worldbank.org/indicator/EA.PRD.AGRI.KD/ countries?display=default, access date $10^{\text {th }}$ May 2014. 


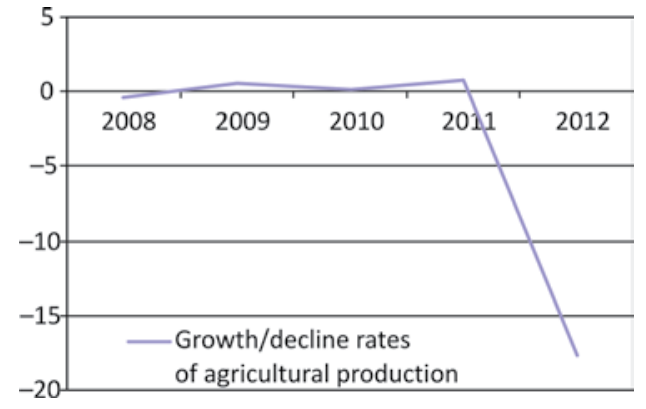

Fig. 4. Growth/decline rates of agricultural production in the Republic of Serbia in the period 2008-2012.

Source: SORS, Statistical Yearbook 2011, Statistical Yearbook 2013.

agricultural production has not recorded some significant increase (base index $2005=100$ ), and in the year 2012 was decreased for almost $17.7 \%$ (see Fig. 4).

\section{Regional diversities and rural poverty.} Although in gross domestic product of rural areas, a dominant share has the activity "Agriculture, Forestry and Fishery" (the share of agriculture in GDP of rural areas amounts around 30\%), realized gross domestic product per capita in these areas (data for the year 2004), has been lower for one forth from the national average of the republic [the National Program of Rural Development of the Republic of Serbia 2011-2013, p. 9].

Professor Bogdanov [2007] points out that economic structure of Serbian rural areas has been highly dependent from the primary sector (dominate agriculture, food industry, mining and energy), and still have been based on depletion of natural resources; dominates the traditional, mono-functional and low productive agriculture, while the rural population represents the poorest socioeconomic category in the Republic of Serbia.

The authors [Mijačić, Paunović, 2011, p. 379] point out to the expressed regional dissimilarities at all Nomenclature of Territorial Units for Statistics (NTUS) levels, which are among the greatest in Europe, as well as to data that, of 45 under developed municipalities in Serbia, those 30 had never changed their level of development in more than 4 decades, and even the regional disparities had been accelerated in the period 2001-2010.

According to the Opinion of the European Economic and Social Committee on Rural Development and Employment in the countries of West Balkan in 2011 [Stantič, 2011], some of developmental limitations of rural areas are: a) under developed physical infrastructure, b) under developed and remote infrastructure which provides social and health care services, education, culture, sports services, etc., c) under developed labour, capital, agricultural market, d) low level of entrepreneurship of rural population and local authorities.

The authors [Živkov, et al., 2012, pp. 10, 11] point out that Serbia is among the most rural countries in Europe, with unfavourable parameters for development of rural areas, especially regarding infrastructure, education, employment access point of view. According to those authors, in the future is possible to improve the condition in rural areas, only in a way it will realize overall economic development, which does not occur where the administration wants it to be seen, but where the economy wishes to invest. In accordance to the same source, the signals sent by agrarian, but also the whole economic policy in Serbia are so variable, unstable and erroneous, that even in case of their change, in the near future, these policies will not decisively affect to directing activities of population in rural areas.

Numerous studies in the field of rural development and life standard [Life Standard Study, 2008, pp. 146-147; Bogdanov, 2007; Cvejić et al., 2010, pp. 14, 61], point out to low productivity of agricultural production, first of all, due to its extensive character, which lead to low gains and low life standard of rural population.

III. Migrations and threatening of demographic structure of rural areas. In the period from 1991 to 2002, the population in rural areas of the Republic of Serbia had been 
decreased for $3.6 \%$ in comparison with the total decline of $1 \%$ at the state level [National Program of Rural Development 2011-2013, pp. 11, 12]. According to the same source, it is especially migrations of young population (especially female population) towards bigger urban centres, which leads to an unequalized regional development and unfavourable age structure of population in rural areas.

\section{RECOMMENDATIONS FOR} STRENGTHENING THE COMPETITIVENESS OF AGRICULTURAL SECTOR AND RURAL REGIONS IN SERBIA

In order that small and medium agricultural husbandries in Serbia (which dominate in structure of the total husbandries) would improve their physical and economic performances (through ensuring the stable and high income sources on the husbandry) and become more competitive on domestic and foreign market, it is necessary that the agricultural producers engage more active on elimination of their numerous internal limitations in the fields of:

- Education, acquiring new knowledge and skills, better awareness, etc.

- Development of entrepreneurial and competitive spirit,

- Better apply of innovation in production and business, which are not and must not be always connected to great financial investments,

- Changes in consciousness and mentality in directions of a real recognition of: own mistakes and problems, significance of investments into products of higher-processing-phase, as well as the significance and importance of introduction of quality standards, improvement of products quality, etc.

Maybe the most important is raising the awareness of agricultural producers regarding necessity of over viewing own development in long-term, regarding that mostly, due to a short term interest, the agricultural producers neglect the general interests and established business agreements with a cooperative, association, etc.

Besides these activities which are in domain of the agricultural producers, it is important that husbandries get support of the political leaders, in form of a stimulating economic and agrarian policy, developed institutional capacities of the state, as well as developed physical, market, financial and innovation infrastructure in the country.

Below measures of agricultural husbandries strengthening will be discussed, which have been under the state's authority, i.e. the government of the Republic of Serbia, and in accordance to the legal [Law on agriculture and rural development, Official Gazette of the Republic of Serbia, No. 41/2009 and 10/2013 - the state law; Law on incentives in agriculture and rural development, Official Gazette of the Republic of Serbia, No. 10/2013] and strategic framework in the field of agriculture and rural development in Serbia and the EU in the period after the year 2014 [Draft of the Agricultural and Rural Development Strategy for the period 20142024; National priorities for the international support for the period 2014-2017, with projections till 2020; The CAP towards 2020: Meeting the food, natural resources and territorial challenges of the future, EC 2010; Regulation (EU) No 1305/2013].

According to Liefert and Swinnen [2002, p. 28] for improvement of agriculture and rural areas competitiveness in the field of transitional countries, the growth of productivity in agriculture is more significant factor than the agricultural production growth, because it only can lead to income increase in agricultural sector and the growth of rural population life standard. Taking it into consideration, aiming to make conditions for property consolidation and productivity growth (through modernization of husbandries, investments in technicaltechnological improvement of agricultural 
production, processing and sale), it will be important the state's support in form of: a) predictable and stimulating agrarian policy and b) development of financial market for attracting the external funding sources: establishing the efficient credit mechanisms, adjusted to the specific and long-term needs for crediting the agricultural producers (adjustment of terms and conditions for credit disbursement), development of nonbanking institutions, etc.

Market development: a) of agricultural products (efficient policy of competition protection in the field of "grey" economy and control of some companies dominant position misuse; development of commercial inscriptions market; terminal market; implementation of intervention repurchase in case of obvious "mistakes" of the market; development of cargo terminals and logistics centres; b) financial market (money and capital); c) land (change of policy in the field of land inheritance; land turnover; setting the efficient system of land management, etc.); d) knowledge (ensuring the efficient transfer of knowledge, information and innovations by the agricultural extension service to agricultural producers). More on the competition development on the agricultural market in Serbia can be seen in [Paraušić et al., 2010a].

\section{Creating a stimulating business environment}

for greater investments in agricultural production and non-agricultural activities (through minimizing investment risk), for employment increase, development of cooperatives and the sector of small and medium enterprises and entrepreneurship (SMEs). Creating the stimulating business environment implies adjustment of: a) tax policy (reducing tax and non-fiscal charges); b) labour legislation, c) trade regulations and d) generally the measures of economic and agrarian policy. Anyhow, the attitudes of the Serbian Association of Employers [Terms and burdens in the Serbian economy, 2010; Attitudes of employers on business environment, 2013] point out constantly on numerous elements of unfavourable business environment, for the SMEE sector activities.

Improvement of rural population life quality and making favourable conditions for diversification of income and the rural population activities, which imply: a) improvement of physical and social infrastructure in the country, b) creating the stimulating business environment and c) making conditions for overall economic development (development of industrial production, service activities). Previously, it aimed to provide the favourable conditions for employing the rural population beyond agriculture (in context of income and activities diversification), which will be necessarily in the period to come, with increase of productivity and decrease of a number of needed employees in agriculture.

\section{Building administrative capacities (in the} Ministry of Agriculture and the Environment Protection of the Republic of Serbia and the Ministry of Finances of the RS) for using IPARD funds (pre-accession funds of the EU meant for rural development in the West Balkan countries), which is also stated in the EC Report on Serbian progress for the year 2013 in the field of Agriculture and Rural Development [EC Report on progress of Serbia for the year 2013]. Serbia has no opportunities to use the IPARD funds in the period $2013+3$, in regard that it had no possibility to fulfil the EC administrative requirements till 2013. In the document adopted by the Government of the Republic of Serbia in 2013 [National priorities for the international support for the period 20142017, with projections till 2020, p. 244] is stated that the IPARD operational structure and the IPARD measures are going to be defined and accredited in the year 2016, while in 2017 will be signed authorization transfer for the IPARD funds management. The group of authors [Živkov, et al., 2012] point out that in Serbia, neither is administration ready to adjust to the EU planning system and implementation of measures for rural development, nor the population is qualified to use the EU funds for rural development 
(insufficiently developed local action groups, public-private partnership, insufficient information of the rural population, etc.).

Development of public institutions (establishment of the rule of law through the efficient legislative and juridical power) which ensures/provides: a) passing necessary laws and an efficient application of the laws, b) contracts compliance, the efficient protection of proprietary rights and an equal access of all participants to the resources, commodity market, financial market, c) building trust among agricultural producers/ entrepreneurs, as well as the trust between civil society and economy and governmental authorities, institutions, agencies, etc. See more [Paraušić, et al., 2007].

\section{CONCLUSIONS}

Strengthening the domestic agricultural producers' competitiveness is a crucial issue of domestic agriculture. Of this is dependant a balanced regional development of the country, development of competitive and attractive rural regions, possibility of rural population employment, as well as staying of the rural population in the country and village survival.

The authors in the paper were analyzed agricultural production and rural regions in Serbia and were pointed out to numerous problems in this field, which have manifested though low productivityand competitiveness of domestic production, underused ability to export, underdevelopment and poverty of rural areas.

In order that small and medium agricultural husbandries, which dominate in agriculture of Serbia, should improve their physical and economic performances and become more competitive, it is necessary, maybe the most important, to engage more active the agricultural producers on removing their numerous internal limitations, which repose in mentality and under developed consciousness on future development. Besides, it is important that husbandries get support of political leaders, through implementation of numerous measures of support: a) insurance of predictable and stimulating agrarian and total economic policy, b) market development (agricultural products, capital, land), c) creating a stimulating business environment for greater investments, employment, overall economic development of the country and diversification of income and rural population activities.

\section{ACKNOWLEDGEMENT}

The paper is a result of the project III 46006 and 47007, funded by the Ministry of Education, Science and Technological Development of the Republic of Serbia.

\section{REFERENCES}

1. Attitudes of employers on the business environment (2013). Serbian Union of Employers, Belgrade, May 2013.

2. Bogdanov Natalija (2007). Small rural households in Serbia and rural non-agricultural households. UNDP, Belgrade.

3. Cvejić S., Babović M., Petrović M., Bogdanov N. Vuković O. (2010): "Social exclusion in rural areas of Serbia", UNDP 2010.

4. Draft Strategy of Agriculture and Rural Development of the Republic of Serbia 20142024, Ministry of Agriculture and the Environment Protection of RS, November 2013.

5. Liefert W., Swinnen J. (2002). Changes in Agricultural Markets in Transition Economies, Agricultural Economic Report No. 806, March 2002, Washington, USDA Economic Research Service.

6. Law on agriculture and rural development, Official Gazette of RS No. 41/2009 and 10/2013 - state law.

7. Law on incentives in agriculture and rural development, Official Gazette of RS No. 10/2013.

8. Mijačić Dragiša, Paunović Blagoje (2011). Regional dissimilarities in Serbia, Ekonomika preduzeća, No. 7-8, 2011. 
9. National Program of Rural Development of the Republic of Serbia 2011-2013, Official Gazette No. 15/2011.

10. National priorities for the international support for the period 2014-2017 with projections till 2020, Government of the Republic of Serbia, 8 ${ }^{\text {th }}$ November 2013.

11. Paraušić Vesna (2007). Institutional and infrastructural barriers of the Republic of Serbia competitiveness: evaluation of the international institutions. International problems, No. 4/2007.

12. Paraušić Vesna, Drago Cvijanović, Vladana Hamović (2010). Cluster approach to improvement of livestock production competitiveness in the Republic of Serbia. Zbornik Matice srpske za društvene nauke, No. 130.

13. Paraušić Vesna, Mihailović Branko, Vladana Hamović (2010a). Imperfect Competition in the Primary Agricultural Commodity Market in Serbia, Economic Annals, No. 184.

14. Paraušić Vesna, Cvijanović Drago, Vuković Predrag (2013). Analysis of the actual indicators of competitiveness in the Serbian agricultural sector. Thematic proceeding: "The new solutions of the CAP 2013 + to the challenges of the EU member states agriculture", Institute of agricultural and food economics national research Institute, No. 91.1 Warsaw 2013.

15. Paraušić Vesna, Cvijanović Janko (2014). Competitiveness of agro-economy of Serbia: clusters in terms of sustainable regional competitiveness. Institute of Agricultural Economics, Belgrade.

16. Report on Serbian progress for 2013 (2013). European Commission, Brussels, 16 ${ }^{\text {th }}$ October 2013, SWD (2013) 412.

17. REGULATION (EU) No. 1305/2013 OF THE EUROPEAN PARLIAMENT AND OF THE COUNCIL of 17 December 2013 on support for rural development by the European Agricultural Fund for Rural Development (EAFRD) and repealing Council Regulation (EC) No. 1698/2005, Official Journal of the EU, 20.12.2013.

18. Stantič Cveto (2011). Opinion of the European Economic and Social Committee on Rural Development and Employment in the West Balkan countries. Brussels, $21^{\text {st }}$ September 2011, REX/322.

19. Study on the Life Standard, Serbia 2002-2007 (2008). Statistical Office of the Republic of Serbia, the World Bank, DFID (Department for International Development), 2008.

20. Terms and burdens in economy of Serbia: State analysis in branch of agriculture and food industry (2010). Serbian Union of Employers, Austrian Development Cooperation (ADC).

21. The CAP towards 2020: Meeting the food, natural resources and territorial challenges of the future (2010). European Commission, Brussels, 18 November 2010, COM (2010) 672 final.

22. The State of food and agriculture (2012). FAO, Rome, 2012.

23. Živkov Goran et al. (2012). The future of the Serbian villages. Team for social inclusion and poverty reduction, Government of the Republic of Serbia.

\section{INTERNET AND STATISTICAL SOURCES}

1. Census of agriculture 2012, Agriculture in the Republic of Serbia, Book I (2013). Statistical Office of the Republic of Serbia, 2013.

2. Labour Survey 2013 (2014). Bulletin No. 578, Statistical Office of the Republic of Serbia, 2014.

3. Serbia Investment and Export Promotion Agency SIEPA, http://siepa.gov.rs/sr/index/ sporazumi (access date $5^{\text {th }}$ April 2014).

4. Statistical base of the Statistical Office of the Republic of Serbia, SORS http://webrzs.stat. gov.rs/WebSite/public/ReportView.aspx (access date 10 th April 2014).

5. Statistical Yearbook of the RS 2011, Statistical Office of the Republic of Serbia, Belgrade 2011.

6. Statistical Yearbook of the RS 2013, Statistical Office of the Republic of Serbia, Belgrade 2013.

7. Statistical base of EUROSTAT, epp.eurostat.ec.europa.eu, (access date $10^{\text {th }}$ May 2014).

8. Statistical base of the World Trade Organization/WTO, http://stat.wto.org (access date $10^{\text {th }}$ March 2014).

9. Statistical base of the World Bank, http://data.worldbank.org, (access date 10 ${ }^{\text {th }}$ May 2014.

10. Statistical FAO base, http://faostat.fao.org (access date $15^{\text {th }}$ May 2014). 


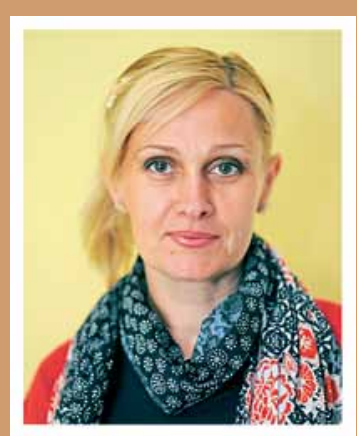

Vesna Parausic PhD, Research Associate, works at the Institute of Agricultural Economics, Belgrade, Serbia. She graduated from the Faculty of Economics, University of Belgrade, and defended doctoral dissertation on the topic "Agricultural clusters in Serbia" at Megatrend University, Faculty of Business Studies in Belgrade. She primarily deals with the problems of building and strengthening the competitiveness of Serbian agriculture producers, through the affirmation of networking and development of agricultural and capital markets. She has been engaged in areas of sustainable rural development and socioeconomic development of local communities and regions. She has published a number of monographs and scientific papers in the field of agriculture, rural development, competitiveness and clusters.

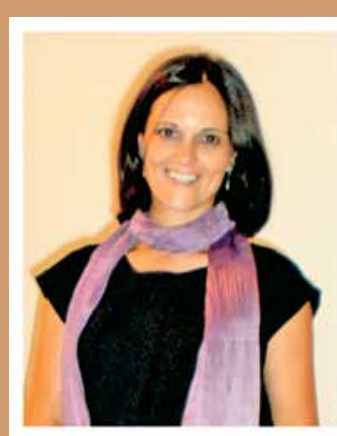

Ivana Simeunović is Associate Professor at the Faculty for Banking, Insurance and Finance, Union University. She teaches courses on Financial Mathematics, Financial Statistics, Actuarial Mathematics, Insurance (graduate studies), Management Science, Quantitative Methods in Finance and Multivariate analysis (postgraduate studies). Her scientific interest refers to Actuarial Science (Risk analysis and assessment, Estimation of expected claims, Loss reserving, Premium calculation), Statistical Data Analysis, Financial Mathematics. She published two books in the field of Financial Mathematics and Financial Statistics as well as numerous papers related to foregoing topics. She is member of Serbian Actuarial Association, Member of Council of the Faculty and Head of the Actuarial Training at Belgrade Banking Academy.

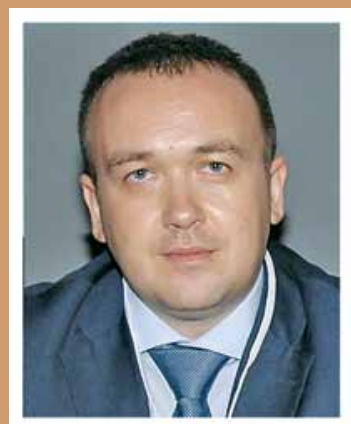

Darko Vukovic is Assistant Professor at the Belgrade Banking Academy (Faculty for Banking, Insurance \& Finance). He graduated in 2005 from the Faculty of Economics in Belgrade, department of economics analyses and politics. At the same faculty he obtained MSc degree in Governing the State in the Market Economy. In 2013, he completed doctoral dissertation at the University of Kragujevac, Faculty of Economics (economics and finance). In 2007 he also attended specialized program in the field of Human Resource Management (Wirtschafts Universitat Wien - classes: Bucharest, Belgrade, Zagreb, Budapest, Vienna, Bratislava, and Prague), where he obtained a diploma in the field of human resource management in multinational companies. Since 2008 he works at Geographic Institute "Jovan Cvijic" of the Serbian Academy of Sciences and Arts, as an associate researcher of the department of regional economics and economic geography. In 2009-2013, Darko Vukovic has worked at the Faculty of Entrepreneurial Business, University Union - Nikola Tesla in Belgrade, as a teaching assistant in the scientific field of economics and finance. Since 2013, he works at the Belgrade Banking Academy - Faculty for Banking, Insurance \& Finance, as an Assistant Professor. 